\title{
Tingkat Partisipasi dalam Kegiatan Pendidikan Kecakapan Hidup
}

\section{The Level Participation of the Life Skill Education Activities}

\author{
Lina Asnamawati ${ }^{1}$, Ninuk Purnaningsih ${ }^{2}$, Soenarmo J. Hatmodjosoewito ${ }^{2}$ \\ ${ }^{1}$ Program Studi Agribisnis, Universitas Terbuka, Bengkulu \\ ${ }^{2}$ Program Studi Ilmu Penyuluhan Pembangunan, \\ Sekolah Pascasarjana Institut Pertanian Bogor, Bogor
}

\begin{abstract}
Life skill education is an essential thing that must be owned by people to gain knowledge and practical skill in particular work fields. The success of life skill education was determined by the direct involvement of the society based on the planning, implementation, evaluation, and benefit of the result. The society would have involved in an activity if it was appropriate with the necessity, the interest, the aptitude, and the availability and the continuity of the source so that the society can apply the skill and the knowledge which are required for themselves and are useful for teaching the local society. The participation of the society was influenced by age, level of formal and informal education, attitude toward life skills, level of knowledge of life skills, functional skills, previous experience about life skills, the guidance of facilitators, and also the availability of supported facilities. According to Arstein, the participation of the society included in tokenism group which is the involvement due to the push in order to make them agree, the announcement of the same direction, the advice from the society is accepted but anyhow it became useless. The degree of the participation from the society gives much effect toward the success of life skill education in attitude change related to personal skill and academic skill. The attitude is also seen in social and vocational skills.
\end{abstract}

Keywords: the level participation, life skills

\begin{abstract}
Abstrak
Pendidikan kecakapan hidup merupakan hal penting yang harus dimiliki masyarakat untuk memperoleh pengetahuan dan keterampilan praktis dibidang pekerjaan tertentu. Keberhasilan pendidikan kecakapan hidup ditentukan keterlibatan masyarakat secara langsung dari perencanaan, pelaksanaan, evaluasi dan menikmati hasil. Masyarakat akan berpartisipasi dalam sebuah kegiatan jika sesuai dengan kebutuhan, minat, bakat, dan ketersediaan sumberdaya serta berkelanjutan sehingga masyarakat mampu menerapkan pengetahuan dan keterampilan yang diperolehnya untuk dirinya sendiri dan dapat digunakan untuk mengajarkan kepada masyarakat sekitarnya. Partisipasi masyarakat dipengaruhi oleh tingkat pendidikan formal, sikap terhadap life skills, tingkat pengetahuan tentang life skills, keterampilan fungsional, pengalaman life skills sebelumnya, pendampingan oleh fasilitator serta ketersediaan sarana dan prasarana. Berdasarkan teori Arnstein partisipasi masyarakat termasuk kedalam kelompok tokenism yaitu keterlibatan karena dorongan agar masyarakat setuju, pemberitahuan yang searah, saran masyarakat diterima tapi tidak selalu dipakai.
\end{abstract}

Kata kunci: tingkat partisipasi, pendidikan kecakapan hidup

\section{Pendahuluan}

Pendidikan kecakapan hidup merupakan hal penting yang harus dimiliki masyarakat untuk memperoleh pengetahuan dan keterampilan praktis dibidang pekerjaan tertentu. Pendidikan kecakapan hidup merupakan proses untuk memperoleh pengetahuan dan keterampilan yang dapat memberikan bekal keterampilan yang praktis, dapat digunakan untuk mencari kerja, terkait dengan kebutuhan pasar kerja, peluang usaha dan potensi ekonomi atau industry yang ada di masyarakat. Jenis pendidikan kecakapan hidup merupakan kemampuan komunikasi secara efektif, kemampuan mengembangkan kerjasama, melaksanakan peranan sebagai warga negara yang bertanggungjawab, memiliki kesiapan serta kecakapan untuk bekerja (Anwar, 2004).

Penyelengaraan pendidikan kecakapan hidup (life skills) akan bermanfaat dengan baik jika terdapat partisipasi aktif dari masyarakat untuk mengikuti program tersebut. Pendidikan kecakapan hidup yang diberikan berupa berbagai macam pelatihan yang dibutuhkan masyarakat. Pelatihan yang diberikan berupa: handycraft, membatik, menjahit, membuat makanan, bunga, aksesories, hiasan dinding dan mute, serta pembuatan sepatu. Menurut Brolin (1989) pendidikan kecakapan hidup 
merupakan suatu pendidikan yang dapat memberikan bekal keterampilan sehingga seseorang dapat hidup mandiri, pendidikan yang dimiliki yaitu kecakapan sehari-hari, kecakapan pribadi dan kecapakan untuk bekerja.

Tujuan pendidikan kecakapan hidup untuk memajukan dan memberdayakan masyarakat. Pendidikan kecakapan hidup dilakukan dengan cara memberikan ilmu, melatih bakat, minat, wawasan, keterampilan serta motivasi untuk berwirausaha. Kemampuan tersebut dapat dimanfaatkan untuk menciptakan peluang kerja mandiri, baik disektor formal maupun informal, sehingga dapat meningkatkan kesejahteraan diri dan keluarganya.

Kegiatan pendidikan kecakapan hidup mendapatkan dukungan pemerintah Undang-Undang RI nomor 20 tahun 2003 tentang sistem pendidikan nasional padapasal26ayat 3 menyebutkanpendidikan non formal meliputi pendidikan kecakapan hidup (life skills), pendidikan anak usia dini, pendidikan kepemudaan, pendidikan pemberdayaan perempuan, pendidikan keaksaraan, serta pendidikan lain yang ditunjukkan untuk mengembangkan kemampuan peserta didik. Pendidikan kecakapan hidup adalah pendidikan yang memberikan kecakapan personal, kecakapan sosial, kecakapan intelektual dan kecakapan vokasional untuk bekerja atau usaha mandiri.

Pendidikan kecakapan hidup memiliki kontribusi besar dalam mengurangi jumlah penduduk miskin. Kemiskinan merupakan suatu keadaan dimana seseorang tidak sanggup memelihara dirinya sendiri dengan taraf kehidupan kelompok dan juga tidak mampu memanfaatkan tenaga mental maupun fisiknya dalam kelompok tersebut (Soekanto, 2002). Data Badan Pusat Statistik (2012) jumlah penduduk miskin mencapai 28,59 juta orang (11,66\%). Kategori masyarakat miskin yaitu masyarakat yang berpenghasilan per bulan Rp 233.000,- (BPS, 2012). Masyarakat akan berpartisipasi dalam sebuah kegiatan jika sesuai dengan kebutuhan, minat, bakat, dan ketersediaan sumberdaya. Kegiatan yang sesuai kebutuhan akan berkelanjutan sehingga masyarakat mampu menerapkan pengetahuan dan keterampilan yang diperolehnya untuk dirinya sendiri dan dapat digunakan untuk mengajarkan kepada masyarakat sekitarnya. Partisipasi merupakan keterlibatan masyarakat dalam pengambilan keputusan, dalam pelaksanaan program melalui sumbangan pemikiran, evaluasi kegiatan dan menikmati hasil (Cohen dan Uphoff, 1977).

Pendidikan kecakapan hidup yang dilakukan untuk memberdayakan masyarakat melalui Pusat Kegiatan Belajar Masyarakat (PKBM). PKBM jelita di desa Kota Batu Kecamatan Ciomas dan PKBM Nurul Huda di desa Cibitung Tengah, Kecamatan Tenjolaya. Oleh karena itu, menarik untuk diteliti mengenai tingkat partisipasi masyarakat desa dalam kegiatan pendidikan kecakapan hidup.

Partisipasi masyarakat sangat penting dalam kegiatan pendidikan kecakapan hidup. Faktor yang mempengaruhi partisipasi masyarakat yaitu karakteristik individu berupa umur, tingkat pendidikan formal, pendidikan non-formal, sikap terhadap life skills, motivasi terhadap life skills, tingkat pengetahuan tentang life skills, keterampilan fungsional, dan pengalaman life skills sebelumnya. Profil Kegiatan yang mempengaruhi partisipasi berupa manajemen kegiatan life skills, pendampingan oleh fasilitator dalam kegiatan life skills, peran pemimpin dalam kegiatan life skills, serta sarana dan prasarana dalam kegiatan life skills. Partisipasi masyarakat dapat dikaji dari beberapa hal, menurut Cohen dan Uphoff (1977) untuk jenis partisipasi dibagi menjadi empat yakni:(1) partisipasi dalam pengam-bilan keputusan (perencanaan), (2) partispasi dan pelaksanaan, (3) partisipasi dalam evaluasi, dan (4) menikmati Hasil. Partisipasi dianalisis dengan tingkat partisipasi menurut Arnstein (1969) yang terdiri dari delapan tingkatan yang mencakup manipulatif, terapi, pemberitahuan, konsultatif, penenangan, kemitraan, pendelegasian dan kontrol masyarakat.

Tujuan penelitian adalah sebagai berikut: (1) menganalisis karakteristik individu dan profil kegiatan dalam kegiatan pendidikan kecakapan hidup (2) menganalisis tingkat partisipasi masyarakat dalam kegiatan pendidikan kecakapan hidup, (3) menganalisis pengaruh antara karakteristik individu dan profil kegiatan terhadap tingkat partisipasi dalam kegiatan pendidikan kecakapan hidup.

\section{Metode Penelitian}

Penelitian ini menggunakan metode survei yang mengambil sampel dari satu populasi dengan menggunakan kuesioner sebagai alat pengumpul data. Lokasi penelitian pada Pusat Kegiatan Belajar 
Masyarakat (PKBM) yang ada di Kabuaten Bogor. PKBM Nurul Huda yang berada di Desa Cibitung Tengah dan PKBM Jelita yang ada di Desa Kota Batu. PKBM sebagai salah satu penyelenggara kegiatan pendidikan kecakapan hidup. Menurut Sevilla et al. (2006) jika jumlah populasi sangat kecil $(<500)$, maka untuk sampelnya diperlukan minimum 20\%. Sampel pada penelitian ini diambil $25 \%$ dari jumlah populasi yaitu 40 responden yang merupakan warga belajar PKBM Nurul Huda dan 43 responden warga belajar PKBM Jelita. Analisis data menggunakan regresi linier berganda untuk mengukur pengaruh antara lebih dari satu variabel bebas $(\mathrm{x})$ terhadap variabel terikat $(\mathrm{Y})$. Persamaan regresi digunakan untuk memprediksi nilai $\mathrm{Y}$ untuk nilai X tertentu (Nazir, 2011).

\section{Hasil Dan Pembahasan}

\section{Karakteristik Individu}

Karakteristik individu dalam penelitian ini merupakan karakteristik sosiodemografi yang menggambarkan perbedaan masyarakat berdasarkan umur, tingkat pendidikan formal, pendidikan nonformal, sikap terhadap life skills, motivasi terhadap life skills, tingkat pengetahuan tentang life skills, keterampilan fungsional dan pengalaman life skills sebelumnya. Hasil analisis tertera pada Tabel 1.

Hasil penelitian menunjukkan sebagian besar responden masuk dalam kategori usia produktif yaitu usia 15-65 tahun. Tingkat pendidikan formal tergolong sedang $(60 \%)$ yaitu pada pendidikan SLTP dan SLTA, Pendidikan non-formal rendah (75\%) responden tidak pernah mengikuti kegiatan penyuluhan dan pelatihan sebelum mengikuti kegiatan pendidikan kecakapan hidup, responden menunjukkan sikap positif terhadap kegiatan pendidikan kecakapan hidup (81,93\%), motivasi responden tergolong sedang $(49,40 \%)$ keinginan mengikuti kegiatan sebagian besar $(86 \%)$ dikarenakan keinginan untuk menambah pengalaman dan jaringan usaha.

Tingkat pengetahuan responden tentang life skills tergolong tinggi $(71,08 \%)$ bahwa mayoritas responden telah mengetahui beberapa produk kerajinan dan cara pembuatannya sebelum mengikuti kegiatan pendidikan kecakapan hidup. Responden memiliki keterampilan fungsional tergolong sedang
$(55,42 \%)$ sebanyak satu sampai dua keterampilan yang dimiliki. Pengalaman life skills sebelumnya berkaitan dengan pengalaman bekerja tergolong rendah $(54,22 \%)$ artinya sebagian besar responden belum pernah bekerja sebelum mengikuti kegiatan pendidikan kecakapan hidup.

Hasil uji beda Mann Whitney menunjukkan umur, sikap terhadap life skills, dan pengalaman dalam life skills menunjukkan perbedaan antara responden pada PKBM Nurul Huda dan PKBM Jelita. Peubah tingkat pendidikan formal, pendidikan non-formal, motivasi terhadap life skills, tingkat pengetahuan tentang life skills dan keterampilan fungsional tidak terdapat perbedaan antara responden pada PKBM Nurul Hudan dan PKBM Jelita.

\section{Profil Kegiatan}

Profil kegiatan pendidikan kecakapan hidup mencakup manajemen kegiatan life skills, pendampingan oleh fasilitator, peran pemimpin dalam life skills, sarana dan prasarana life skills. Tabel 2 menunjukkan manajemen kegiatan sebanyak $43 \%$ reponden merasakan kesempatan untuk terlibat dalam kegiatan pendidikan kecakapan hidup berada dalam kategori sedang dan 28\% responden terlibat dalam kategori tinggi. Artinya kesempatan yang diberikan kepada warga belajar untuk terlibat cukup besar.

Pendampingan oleh fasilitator telah dilaksanakan dengan baik atau tinggi, sebanyak $68,67 \%$ telah sesuai ketentuan penyelenggara. Secara keseluruhan peranan pemimpin formal dan informal masih rendah $(54,22 \%)$. Hal ini menunjukkan warga belajar dalam mengikuti kegiatan pendidikan kecakapan hidup kurang mendapatkan peranan dari pemimpin baik tokoh masyarakat maupun pamong desa. Kelengkapan sarana dan prasarana akan mendukung kelancaran operasional kegiatan oleh PKBM karena tanpa prasarana yang lengkap akan menjadi kendala kegiatan pendidikan kecakapan hidup.

Hasil uji beda Mann Whitney menunjukkan tidak terdapat perbedaan peubah manajemen kegiatan life skills, pendampingan oleh fasilitator, sarana dan prasarana dalam kegiatan life skills. Peubah peran pemimpin dalam life skills antara responden pada PKBM Nurul Huda terdapat perbedaan dengan responden PKBM Jelita. Pemimpin yang berada di 
Tabel 1 Karakteristik Individu

\begin{tabular}{|c|c|c|c|c|c|}
\hline \multirow[t]{2}{*}{ Sub Variabel } & Kategori & $\begin{array}{c}\text { PKBM Nurul } \\
\text { Huda }\end{array}$ & PKBM Jelita & Total & $\begin{array}{c}\text { Uji Beda Mann } \\
\text { Whitney }\end{array}$ \\
\hline & & $\%$ & $\%$ & $\%$ & Signifikansi \\
\hline \multirow[t]{4}{*}{ Umur } & Remaja Awal & 60,00 & 37,00 & 48,00 & 0,001 \\
\hline & Muda & 28,00 & 33,00 & 30,00 & \\
\hline & Dewasa & 10,00 & 14,00 & 12,00 & \\
\hline & Tua & 3,00 & 16,00 & 10,00 & \\
\hline \multirow{3}{*}{$\begin{array}{l}\text { Tingkat } \\
\text { pendidikan } \\
\text { formal }\end{array}$} & Rendah & 45,00 & 35,00 & 40,00 & 0,539 \\
\hline & Sedang & 55,00 & 65,00 & 60,00 & \\
\hline & Tinggi & 0,00 & 0,00 & 0,00 & \\
\hline \multirow{3}{*}{$\begin{array}{l}\text { Pendidikan non } \\
\text { formal }\end{array}$} & Rendah & 78,00 & 70,00 & 75,00 & 0,398 \\
\hline & Sedang & 23,00 & 28,00 & 23,00 & \\
\hline & Tinggi & 0,00 & 2,00 & 1,00 & \\
\hline \multirow{3}{*}{$\begin{array}{l}\text { Sikap terhadap } \\
\text { life skills }\end{array}$} & Rendah & 5,00 & 13,95 & 9,64 & 0,040 \\
\hline & Sedang & 7,50 & 9,30 & 8,43 & \\
\hline & Tinggi & 87,50 & 76,74 & 81,93 & \\
\hline \multirow{3}{*}{$\begin{array}{l}\text { Motivasi life } \\
\text { skills }\end{array}$} & Rendah & 12,50 & 2,33 & 7,23 & 0,937 \\
\hline & Sedang & 42,50 & 55,81 & 49,40 & \\
\hline & Tinggi & 45,00 & 41,86 & 43,37 & \\
\hline \multirow{3}{*}{$\begin{array}{l}\text { Tingkat } \\
\text { pengetahuan } \\
\text { tentang life } \\
\text { skills }\end{array}$} & Rendah & 12,50 & 0,00 & 6,02 & 0,584 \\
\hline & Sedang & 17,50 & 27,91 & 22,89 & \\
\hline & Tinggi & 70,00 & 72,09 & 71,08 & \\
\hline \multirow{3}{*}{$\begin{array}{l}\text { Keterampilan } \\
\text { Fungsional }\end{array}$} & Rendah & 17,50 & 9,30 & 13,25 & 0,679 \\
\hline & Sedang & 45,00 & 65,12 & 55,42 & \\
\hline & Tinggi & 37,50 & 26,00 & 31,33 & \\
\hline \multirow{3}{*}{$\begin{array}{l}\text { Pengalaman } \\
\text { life skills } \\
\text { Sebelumnya }\end{array}$} & Rendah & 72,50 & 37,21 & 54,22 & 0,002 \\
\hline & Sedang & 25,00 & 60,47 & 43,37 & \\
\hline & Tinggi & 2,50 & 2,33 & 2,41 & \\
\hline
\end{tabular}

Desa Kota Batu lebih memberikan peranan kepada masyarakat yang mengikuti kegiatan life skills di PKBM Jelita.

\section{Tingkat Partisipasi Masyarakat}

Partisipasi masyarakat sangat penting diperlukan karena kegiatan yang melibatkan partisipasi aktif dari masyarakat akan berjalan lebih optimal. Masyarakat akan berpartisipasi jika mereka diberdayakan dengan berbagai potensi yang mereka miliki, juga sesuai dengan minat mereka. Pemberdayaan upaya untuk memberikan kesempatan dan kemampuan kepada masyarakat (miskin) untuk mampu memperbaiki hidupnya (Mardikanto, 2009). Ketersediaan sumberdaya sangat dibutuhkan agar masyarakat dapat berpartisipasi aktif. Partisipasi merupakan konsep pengembangan masyarakat, partisipasi sebagai sebuah cara untuk memanfaatkan sumberdaya, menggerakan dan melibatkan masyarakat (Ife dan Tesoriero, 2006).

Partisipasi masyarakat dalam kegiatan pendidikan kecakapan hidup dilakukan diberbagai tempat, salah satunya pada Pusat Kegiatan Belajar Masyarakat (PKBM). PKBM merupakan suatu wadah yang menyediakan informasi dan kegiatan belajar sepanjang hayat bagi warga masyarakat agar lebih berdaya.Keberadaan PKBM sangat bermanfaat untuk memberdayakan masyarakat. PKBM turut serta memfasilitasi masyarakat dalam kegiatan belajar serta sebagai agen pembaharu dalam menyebarkan inovasi agar masyarakat berubah dalam pengetahuan, sikap dan keterampilan menjadi lebih baik. Menurut Rogers dan Schoemaker (1986) peranan yang dijalankan oleh agen pembaharu dalam menyebarkan inovasi antara lain: membangkitkan 
Tabel 2 Profil Kegiatan

\begin{tabular}{llcccc}
\hline \multicolumn{1}{c}{ Sub Variabel } & Kategori & $\begin{array}{c}\text { PKBM Nurul } \\
\text { Huda }\end{array}$ & PKBM Jelita & Total & $\begin{array}{c}\text { Uji Beda } \\
\text { Mann Whitney } \\
\text { Signifikansi }\end{array}$ \\
\hline Manajemen kegiatan life & 1.Rendah & 12,50 & $\mathbf{\%}$ & $\mathbf{\%}$ & 0,544 \\
skills & 2.Sedang & 55,00 & 16,28 & 12,00 & \\
& 3.Tinggi & 32,50 & 48,84 & 43,00 & \\
Pendampingan oleh & 1.Rendah & 5,00 & 34,88 & 28,00 & \\
fasilitator & 2.Sedang & 22,50 & 4,65 & 4,82 & 0,782 \\
& 3.Tinggi & 72,50 & 30,23 & 26,51 & \\
Peran pemimpin dalam & 1.Rendah & 65,00 & 65,12 & 68,67 & \\
life skills & 2.Sedang & 27,50 & 44,19 & 54,22 & 0,039 \\
& 3.Tinggi & 7,50 & 34,88 & 31,33 & \\
Sarana dan prasarana & 1.Rendah & 10,00 & 20,93 & 14,46 & \\
dalam life skills & 2.Sedang & 37,50 & 18,60 & 14,46 & 0,661 \\
& 3.Tinggi & 52,50 & 6,98 & 21,69 & \\
\hline
\end{tabular}

kebutuhan untuk berubah, mengadakan hubungan untuk perubahan, mengidentifikasi masalah sasaran, memotivasi dan merencanakan tindakan perubahan.

Partisipasi merupakan keterlibatan aktif masyarakat dalam proses pengambilan keputusan tentang apa yang akan dilakukan dan bagaimana cara kerjanya, keterlibatan masyarakat dalam pelaksanaan program dan pengambilan keputusan yang telah ditetapkan melalui sumbangan sumberdaya atau bekerjasama dalam suatu kegiatan, keterlibatan masyarakat dalam evaluasi dan menikmati hasil program (Cohen dan Uphoff, 1977).

Tingkat partisipasi masyarakat dianalisis berdasarkan teori Arstein yang membagi partisipasi menjadi delapan tingkat $\neg$ an yaitu: manipulasi, terapi, informasi, konsultasi, tingkat penenangan, kerjasama, pendelegasian wewenang, dan pengawasan oleh masyarakat. Tingkat partisipasi dilihat dari setiap tahapan kegiatan mulai dari perencanaan, pelaksanaan, evaluasi, dan menikmati hasil.

Pendidikan berorientasi kecakapan hidup melalui pendekatan Broad Based Education merupakan pendidikan yang menekankan bekerja. Kegiatan pendidikan kecakapan hidup melibatkan masyarakat dalam tahap kegiatannya (Tabel 3).

\section{Perencanaan}

Partisipasi pada tahap perencanaan adalah keikutsertaan responden dalam menyusun rencana suatu kegiatan. Pada tahap perencanaan yang dinilai adalah keterlibatan dalam bentuk kehadiran, menyampaikan pendapat dan pengambilan keputusan tentang segala sesuatu yang berkaitan dengan kegiatan yang akan dilaksanakan. Responden PKBM Nurul Huda sebanyak 55\% pada tahap (information) merupakan sekedar pemberitahuan searah dari pihak PKBM kepada masyarakat. Pada tahap information yaitu kegiatan yang dilakukan oleh PKBM sekedar melakukan pemberitahuan searah atau sosialisasi kepada warga belajar. Pada tahap information komunikasi sudah banyak terjadi tetapi masih bersifat satu arah dan tidak ada sarana timbal balik. Informasi telah diberikan kepada masyarakat tetapi masyarakat tidak diberikan kesempatan melakukan tanggapan balik.

Responden pada PKBM Jelita sebanyak $44 \%$ pada tahap (delegated power). Pada tahap delegated powermerupakan suatu bentuk partisipasi aktif masyarakat untuk melakukan perencanaan, implementasi dan monitoring. Masyarakat diberikan kekuasaan untuk melaksanakan sebuah program dengan cara berperan merancang kegiatan.

\section{Pelaksanaan}

Partisipasi pada tahap pelaksanaan kegiatan adalah keterlibatan dalam bentuk penyediaan dana, pengadaan sarana, dan korbanan waktu/tenaga 
Tabel 3 Tingkat Partisipasi Masyarakat

\begin{tabular}{|c|c|c|c|c|c|c|c|c|}
\hline \multirow[b]{2}{*}{ Tingkat Partisipasi } & \multicolumn{2}{|c|}{ Perencanaan } & \multicolumn{2}{|c|}{ Pelaksanaan } & \multicolumn{2}{|c|}{ Evaluasi } & \multicolumn{2}{|c|}{ Menikmati Hasil } \\
\hline & $\begin{array}{c}\text { Nurul Huda } \\
(\%)\end{array}$ & $\begin{array}{c}\text { Jelita } \\
(\%)\end{array}$ & $\begin{array}{c}\text { Nurul Huda } \\
(\%)\end{array}$ & $\begin{array}{c}\text { Jelita } \\
(\%)\end{array}$ & $\begin{array}{c}\text { Nurul Huda } \\
(\%)\end{array}$ & $\begin{array}{c}\text { Jelita } \\
(\%)\end{array}$ & $\begin{array}{c}\text { Nurul Huda } \\
(\%)\end{array}$ & $\begin{array}{c}\text { Jelita } \\
(\%)\end{array}$ \\
\hline Manipulation & 3 & 7 & 0 & 2 & 0 & 5 & 0 & 0 \\
\hline Theraphy & 5 & 2 & 5 & 2 & 13 & 12 & 5 & 14 \\
\hline Information & 55 & 37 & 40 & 30 & 55 & 40 & 33 & 35 \\
\hline Counsultation & 20 & 2 & 30 & 9 & 15 & 7 & 25 & 19 \\
\hline Placation & 5 & 2 & 5 & 0 & 13 & 7 & 0 & 0 \\
\hline Partnership & 8 & 5 & 10 & 2 & 0 & 0 & 23 & 26 \\
\hline Delegated Power & 5 & 44 & 20 & 47 & 5 & 30 & 15 & 7 \\
\hline Citizen Control & 0 & 0 & 0 & 7 & 0 & 0 & 0 & 0 \\
\hline
\end{tabular}

sejak persiapan kegiatan, pelaksanaan dan setelah pelaksanaan kegiatan yang berupa pemeliharan hasil-hasil kegiatan. Responden PKBM Jelita sebanyak $47 \%$ pada tahap delegated power diberikan kekuasaan untuk melaksanakan kegiatan sesuai dengan kebutuhan mereka dengan cara ikut memberikan usulan bagi pelaksanaan kegiatan bahkan mengutamakan keinginan dari warga belajar. Responden PKBM Nurul Huda sebanyak $40 \%$ lebih banyak pada tahap information yaitu penyelenggaraan kegiatan pendidikan kecakapan hidup yang dilakukan sekedar melakukan pemberitahuan searah, pada pelaksanaan terdapat komunikasi yang sudah banyak terjadi tetapi masih bersifat satu arah atau tidak ada sarana timbal balik.

\section{Evaluasi}

Keberhasilan dan kegagalan suatu kegiatan dapat diketahui jika kita melakukan evaluasi terhadap kegiatan tersebut. Tahap evaluasi merupakan kegiatan monitoring, pengawasan, dan juga penilaian. Evaluasi memberikan manfaat dan kontribusinya didalam memberikan informasi maupun data, khususnya mengenai pelaksanaan suatu kegiatan. Proses evaluasi dalam kegaiatan pendidikan kecakapan hidup dilakukan secara internal oleh pihak PKBM, serta melibatkan warga belajar yang dilakukan setelah kegiatan selesai dilaksanakan. Pada PKBM Nurul Huda maupun PKBM Jelita kegiatan evaluasi merupakan sekedar informasi dari pihak PKBM kepada warga belajar. Pada tingkat partisipasi responden terbanyak pada tahap information sebanyak 55\% pada PKBM Nurul Huda dan 40\% pada PKBM Jelita. Evaluasi yang dilakukan sekedar pemberitahuan searah dari pihak PKBM kepada warga belajar.

\section{Menikmati Hasil}

Pendidikan kecakapan hidup dimaksudkan pada penguasaan keterampilan praktis agar warga belajar dapat memanfaatkan keterampilan sebagai bekal hidup agar dapat berusaha mandiri. Menikmati hasil kegiatan merupakan keterlibatan masyarakat dalam bentuk pemanfaatan teknologi dan hasil kegiatan. Semakin besar manfaat yang dirasakan dari kegiatan pendidikan kecakapan hidup, maka kegiatan tersebut telah berhasil mengenai sasaran atau tepat sasaran. Tahap menikmati hasil kegiatan pada PKBM Nurul Huda sebanyak 33\% dan PKBM Jelita sebanyak 35\% pada tingkatan information. Kegiatan pendidikan kecakapan hidup membuat semakin meningkatkan kualitas hidup masyarakat di sekitar PKBM, walaupun pada saat ini hasil penjualan hasil kerajinan belum mampu memberikan keuntungan besar bagi masyarakat karena pemasaran produk hasil kerajinan masih terkendala untuk memasarkannya.

\section{Tingkat Kelompok Partisipasi}

Tingkat partisipasi masyarakat desa dalam hal ini warga belajar pada PKBM Nurul Huda dan PKBM Jelita mencakup tingkat partisipasi tinggi, sedang rendah. Hasil pengolahan data menunjukkan sebagian besar warga belajar memiliki tingkat partisipasi pada level rendah dan sedang (Tabel 4). Analisis dilakukan menggunakan konsep Arstein dimana hasil pengolahan data menunjukkan bahwa 
Tabel 4 Tingkat Kelompok Partisipasi dalam Kegiatan Pendidikan Kecakapan Hidup

\begin{tabular}{lccc}
\multicolumn{1}{c}{ Tingkat } & PKBM Nurul Huda & PKBM Jelita & Total \\
\multicolumn{1}{c}{ Kelompok Partisipasi } & $\mathbf{\%}$ & $\mathbf{\%}$ & $\mathbf{\%}$ \\
\hline Non Partisipasi & 42,50 & 27,91 & 34,94 \\
Tokenism & 42,50 & 37,21 & 39,76 \\
Power Of Citizen & 15,00 & 34,88 & 25,30 \\
\hline Jumlah & 100,00 & 100,00 & 100,00 \\
\hline
\end{tabular}

warga belajar sebanyak 34,94\% kelompok nonpartisipasi memiliki tipe partisipasi manipulasi dan terapi, yakni hubungan tipe hubungan non partisipasi yaitu sekedar agar masyarakat tidak marah untuk ikut serta dalam kegiatan pendidikan kecakapan hidup. Warga belajar beranggapan bahwa kegiatan pendidikan kecakapan hidup yang dilakukan tidak bertujuan untuk membuat masyarakat lebih memiliki penge-tahuan dan keterampilan yang memadai tapi hanya menjalankan program yang ada. Kegiatan pelaksanaan tidak sesuai dengan yang dijanjikan oleh PKBM. Responden beranggapan ada beberapa hal yang kurang sesuai dengan yang dijanjikan seperti jenis keterampilan, ketersediaan dana, dan sarana yang diperlukan.

Responden sebagian besar sebanyak 39,76\% memiliki tipe partisipasi informasi, konsultasi dan konsiliasi, yakni pada hubungan kekuasaan tokenism yaitu warga belajar diberikan informasi dari PKBM mengenai suatu keputusan namun sebenarnya mereka hanya memiliki sedikit kekuasaan untuk mempengaruhi keputusan tersebut. Hal tersebut dikarenakan pihak PKBM memiliki peranan yang besar untuk mengatur kegiatan pendidikan kecakapan hidup. Warga belajar lebih banyak diberikan wewenang pada kegiatan pelaksanaan, namun mayoritas dari warga belajar kurang mengetahui kegiatan perencanaan dan evaluasi. Tahap perencanaan PKBM dan perwakilan warga belajar melakukan rapat untuk menentukan kegiatan pendidikan kecakapan hidup. PKBM memberikan informasi mengenai kegiatan pendidikan kecakapan hidup, warga belajar juga diberikan kesempatan untuk menyampaikan saran dan juga kritik. Namun keputusan tetap ditentukan oleh PKBM. Pada tahap pelaksanaan PKBM juga memberikan kekuasan kepada warga belajar untuk melakukan kegiatan dengan didampingi oleh fasilitator. Hasil dari kegiatan pendidikan kecakapan hidup yaitu bertambah pengetahuan dan keterampilan warga belajar, namun hasil penjualan produk kegiatan pendidikan kecakapan hidup lebih banyak diatur oleh PKBM yaitu dipasarkan pada saat pameran, namuan ada juga yang dipasarkan secra mandiri oleh warga belajar ke toko-toko atau warung disekitar tempat tinggal mereka.

Tabel 5 Peubah yang mempengaruhi Tingkat Partisipasi Masyarakat

\begin{tabular}{lccl}
\hline \multicolumn{1}{c}{ Peubah } & B & t & Sig \\
\hline Umur & 0,057 & 1,672 & 0,099 \\
Tingkat Pendidikan Formal & 0,702 & 5,083 & $0,000^{* *}$ \\
Pendidikan Non Formal & 1,152 & 1,893 & 0,063 \\
Sikap terhadap Life Skills & 0,722 & 4,977 & $0,000^{* *}$ \\
Motivasi terhadap Life Skills & $-0,576$ & $-3,865$ & $0,000^{* *}$ \\
Tingkat Pengetahuan tentang & 0,469 & 12,086 & $0,000^{* *}$ \\
Life Skills & $-1,470$ & $-2,650$ & $0,010^{* *}$ \\
Keterampilan Fungsional & 1,328 & 3,450 & $0,001^{* *}$ \\
Pengalaman Life Skills sebel- & $-3,031$ & $-0,836$ & 0,406 \\
umnya & & & \\
Constant &
\end{tabular}

Keterangan: signifikan pada taraf 5\% 
Tabel 6 Peubah yang mempengaruhi Tingkat Partisipasi Masyarakat

\begin{tabular}{lccl}
\hline \multicolumn{1}{c}{ Peubah } & B & t & Sig \\
\hline Manajemen kegiatan Life Skills & $-0,034$ & $-0,368$ & 0,714 \\
Pendampingan oleh Fasilitator & 0,524 & 8,640 & $0,000^{* *}$ \\
dalam Life Skills & 0,088 & 1,394 & 0,168 \\
Peran Pemimpin dalam Life Skills & $-0,254$ & $-2,537$ & $0,013^{* *}$ \\
Sarana dan Prasarana dalam Ke- & $-3,031$ & $-0,836$ & 0,406 \\
giatan Life Skills & & & \\
Constant & &
\end{tabular}

Keterangan: signifikan pada taraf 5\%

Tingkat kelompok partisipasi power of citizen sebanyak $25,30 \%$ memiliki tipe partisipasi kemitraan, pendelegasian kekuatan dan kontrol masyarakat yakni partisipasi berdasarkan tingkat kekuasaan ada di masyarakat. Warga belajar diberikan kesempatan untuk aktif meakukan kegiatan secara mandiri, diberikan kesempatan untuk mengambil keputusan untuk menentukan kegiatan pendidikan kecakapn hidup yang dilakukan sesuai dengan minat dan kebutuhan pasar, namun pihak PKBM tetap memberikan dukungan dari fasilitas dan pendamping.

\section{Faktor-Faktor yang Mempengaruhi Tingkat Partisipasi Masyarakat}

\section{Pengaruh Karakteristik Individu Masyarakat}

Karakteristik individu yang berpengaruh positif terhadap kegiatan pendidikan kecakapan hidup yaitu tingkat pendidikan formal, tingkat pengetahuan tentang life skills, sikap terhadap life skills dan pengalaman life skills sebelumnya. Hasil analisis menunjukkan, peningkatan pendidikan satu tahun akan meningkatkan tingkat partisipasi, serta jika tingkat pengetahuan tentang life skills, sikap terhadap life skills dan pengalaman life skills sebelumnya semakin baik maka tingkat partisipasi juga akan meningkat. Pengaruh negatif yaitu pada peubah keterampilan fungsional dan motivasi terhadap life skills artinya walaupun motivasi dan keterampilan fungsional rendah, responden tetap berpartisipasi aktif dalam kegiatan life skills. Responden beranggapan bahwa mengikuti kegiatan pendidikan kecakapan hidup penting untuk meningkatkan kualitas hidup mereka.

Berkaitan dengan umur dan pendidikan non- formal tidak berpengaruh terhadap tingkat partisipasi masyarakat. Umur responden yang semakin tua tidak berpengaruh semakin meningkat partisipasinya, responden yang berada pada umur remaja awal tetap berpartisipasi dalam kegiatan pendidikan kecakapan hidup. Responden yang telah mengikuti pendidikan non formal tidak berpengaruh pada peningkatan partisipasinya.

\section{Profil Kegiatan}

Profil kegiatan yang berpengaruh positif terhadap kegiatan pendidikan kecakapan hidup yaitu pendampingan oleh fasilitator. Hal tersebut dikarenakan semakin baik pendampingan oleh fasilitator maka tingkat partisipasi masyarakat akan semakin meningkat. Sarana dan prasarana dalam kegiatan life skills berpengaruh negatif terhadap tingkat partisipasi masyarakat, Artinya walaupun sarana dan prasarana dalam kegiatan life skills rendah, namun partisipasi masyarakat tetap tinggi. Masyarakat ikut serta menyediakan sarana yang dibutuhkan untuk kegiatan pendidikan kecakapan hidup.

Manajemen kegiatan life skills tidak berpengaruh terhadap tingkat partisipasi masyarakat. Walaupun pengelolaan kegiatan pendidikan kecakapan hidup kurang baik, namun warga belajar berusaha untuk mengikuti kegiatan dengan baik karena mereka beranggapan mengikuti kegiatan pendidikan kecakapan hidup akan menjadi ilmu untuk memperoleh pekerjaan. Peran pemimpin dalam life skills tidak berpengaruh terhadap tingkat partisipasi masyarakat. Hal ini menunjukkan ada atau tidak ada peranan dari pemimpin tidak mempengaruhi keterlibatan warga belajar dalam mengikuti kegiatan pendidikan kecakapan hidup. 


\section{Kesimpulan}

Hasil penelitian dapat disimpulkan (1) Karakteristik individu yang sebagian besar memiliki kategori tinggi yaitu pada sikap responden dan tingkat pengetahuan terhadap life skills. Profil kegiatan yang mencakup pendampingan oleh fasilitator dan sarana prasarana sebagian besar tergolong tinggi (2) Partisipasi warga belajar dalam kegiatan pendidikan kecakapan hidup pada tahap tokenism memiliki tingkatan informasi, konsultasi dan konsiliasi, dimana partisipasi merupakan dorongan dari pihak penyelenggara kegiatan; (3) Karakteristik individu yang berpengaruh positif yaitu tingkat pendidikan formal, tingkat pendidikan formal, sikap terhadap life skills, tingkat pengetahuan tentang life skills serta pengalaman life skills sebelumnya. Profil kegiatan yang berpengaruh pendampingan oleh fasilitator dan sarana prasarana. Manajemen kegiatan life skills dan peran pemimpin dalam life skills tidak berpengaruh terhadap tingkat partisipasi masyarakat.

\section{Daftar Pustaka}

Arnstein SR. 1969. A Ladder Warga Negara Partisipasi. [Internet]. [dapat diunduh dari: http://lithgow-schmidt.dk/sherry-arnstein].

Anwar. 2004. Pendidikan Kecakapan Hidup. Bandung (ID): Alfabeta.

Ahmadi A. 2009. Ilmu sosial Dasar. Jakarta (ID): Rineka Cipta.

Azwar S. 2013. Sikap Manusia (Teori dan Pengukurannya). Yogyakarta (ID): Pustaka Pelajar.

Brolin DE. 1989. Life Centered Career Education: A Competency Based Approach. Reston, VA: The Council for Exceptional Children.

[BPS] Badan Pusat Statistik. 2012. Jumlah penduduk Miskin. [Internet].[dapat diunduh dari: http:// www.bps.go.id].

Cohen J, Uphoff NT 1977. Rural Development Participation Concepts and Measures For Project Design, Implementation and Evaluation Rural Development Committee, Center for international Studies. New York.

[Depdiknas] Departemen Pendidikan Nasional. 2002. Pendidikan Berorientasi Kecakapan Hidup (Life Skill) Melalui Pendekatan Broad-Besed
Education (Draft). Jakarta (ID): Departemen Pendidikan Nasional.

Ife J, Tesoriero F. 2006. Community Development: Alternatif Pengembangan Masyarakat di Era Globalisasi. Yogyakarta (ID): Pustaka Pelajar.

[Kemendiknas] Kementerian Pendidikan Nasional. 2012. Petunjuk Teknis Pengajuan dan Pengelolaan Dana PKBM Tematik. [Internet]. [dapat diunduh dari: http://www.new.paudni. kemendiknas.go.id].

Muljono P, Hanafi DNT. 2009. Pengembangan Program Kecakapan Hidup (Life Skills) untuk Pemberdayaan Masyarakat Sekitar Pesantren (Studi Kasus PKBM Al-Wathoniyah Di desa Sukosono, Kec. Kedung, Kab. Jepara. Proseding Simposium PAPPI :1-20 IPB.

Mardikanto T. 2009. Sistem Penyuluhan Pertanian. Surakarta: UNS Press.

Mohammadia, Akbar, Aghdamb GA, Kiyani R, Sattarzedeh L. 2011. Investigating Effect of Life Skills Training on Family Functioning of Epileptic People's in Tabriz. Procedia - Social and Behavioral Sciences 30 (23): 16 - 2318.

Nazir M. 2011. Metode Penelitian. Bogor(ID): Ghalia Indonesia.

Pretty, Jules N, Irene, Guijt. 1992. Primary Environmental Care: An Alternative Paradigm for Development Assistance. Environment 4(1).

Rahadrjo. 2004. Pengantar Sosiologi Pedesaan dan Pertanian. Yogyakarta(ID): Gadjah Mada University Press.

Rahmawati, Sumarti T. 2011. Analisis Tingkat Partisipasi Peserta Program Pemberdayaan Ekonomi PT. Arutmin Indonesia Kasus di Desa Binaan Tambang Senakin, Kabupaten Kotabaru, Provinsi Kalimantan Selatan). Jurnal Solidity 5 (3).

Rosyida I, Nasdian FT. 2011. Partisipasi Masyarakat Dan Stakeholder Dalam Penyelenggaraan Program Corporate Social Responsibility (CSR) Dan Dampaknya Terhadap Komunitas Pedesaan. Jurnal Solidity 5(1).

Sugiyanto. 2002. Lembaga Sosial. Yogyakarta (ID): Gadjah Mada University Press.

Sumardjo RM. 2006. Faktor-Faktor Yang Berhubungan dengan Proses Belajar dan Tingkat Kecakapan Hidup Remaja (Kasus Pengrajin Sandal Desa Cikaret Kec. Bogor Selatan). Jurnal Penyuluhan 2(2): 115-124. 
Jurnal Penyuluhan, September 2014 Vol. 10 No. 2

Soekanto S. 2002. Sosiologi Suatu Jakarta(ID): Rajagrafindo Persada.

Sevilla CG, Tuwu, Alam SA. 2006. Pengantar Metode Penelitian. Jakarta (ID): UI Press.

Shauna K, Helen H, Marcarthur. C 2007. Preparing for Adulthood:A Systematic Review of Life Skill Programs for Youth with Physical Disabilities (aLife Skills \& Wellness Institute, Bloorview
Kids Rehab, Toronto, Ontario, Canada). Journal of Adolescent Health 41(2007) 323-332.

Soetomo. 2012. Pembangunan Masyarakat. Jakarta (ID): Pustaka pelajar.

Widoyoko. 2010. Evaluasi Program Pembelajaran: Panduan Praktis Bagi Pendidik dan Calon Pendidik. Yogyakarta (ID): Pustaka Pelajar 